Int. J. Odontostomat., 7(2):305-313, 2013.

\title{
The Fresh Frozen Bone Allograft (FFBA) to Reconstruct the Atrophic Maxilla. Evaluation of the Clinical and Histological Viability at Six and Nine Months in the Maxillary Sinus
}

\author{
Aloinjerto Óseo Fresco Congelado (FFBA) en la Reconstrucción del Maxilar Atrófico. Evalua- \\ ción de la Viabilidad Clínica e Histológica a los Seis y Nueve Meses en el Seno Maxilar
}

\author{
Ana Paula F. Bassi"; Rogerio Acedo Vieira**; Marisa Akemi Matsumoto*; \\ Iris Monica Steckelberg ${ }^{* *}$; Gabriel Ramalho-Ferreira ${ }^{* * *}$ \& Leonardo Perez Faverani ${ }^{* *}$
}

BASSI, A. P. F.; VIEIRA, R. A.; MATSUMOTO, M. A.; STECKELBERG, I. M.; RAMALHO-FERREIRA, G. \& FAVERANI, L. P. The fresh frozen bone (FFBA) allograft to reconstruct the atrophic maxilla. Evaluation of the clinical and histological viability at six and nine months in the maxillary sinus. Int. J. Odontostomat., 7(2):305-313, 2013.

ABSTRACT: This work aimed to analyze clinically and histologically the allogen bone graft behavior at 6 and 9 months. A leukoderm, female, 55 years old patient sought dental care for oral rehabilitation with dental implants and implant supported fixed prosthesis in the maxilla. Bilateral sinus lifting procedure were performed in a same patient, the analysis were made after 6 and 9 months, respectively. At 6 months, there was lack of a better bone remodeling in the region, associated to the presence of fibrous connective tissue within the collected tissue, showing us that this is not the best stage of tissue maturation to place dental implants. The 9 months period showed an improvement, with a more organized bone tissue surrounding particles of homogenous bone, what possibly had increased implant stability at the time of surgery. There is no doubt about the increase of clinical applications of FFBA, but there are no studies available regarding the standardization of time to load implants inserted in allografts. So papers with long-term monitoring are necessary to eliminate questions that still remain to be answered.

KEY WORDS: maxillary sinus, fresh frozen human bone, bone histology.

\section{INTRODUCTION}

Increased life expectancy of the world population associated with the advancement of science and technology in dentistry, have allowed the resolution of complex cases from the surgical and prosthetic viewpoint. However, bone resorption after tooth loss, is a large obstacle in the aesthetic and functional rehabilitation of patients (Johansson et al., 2001; Pelo et al., 2009).

The autogenous bone graft is considered the gold standard in scientific literature, being the first choice of professionals for reconstruction of maxillary atrophy, but not always the patient has enough bone in intraoral donor sites, requiring extraoral areas, which increases the morbidity of treatment. Therefore the need for access two surgical sites increases operative and recovery time after surgery, and when associated with systemic disorders, autogenous grafting may be contraindicated (Carvalho et al., 2003; Pelo et al.). In this context, the search for available biomaterials is necessary.

Among these, the following bone substitutes can be detached: allogen, alloplastic and xenogenous bone grafts. The great advantage is no need to access a second surgical site to obtain a reconstructive mate-

School of Dentistry of Araçatuba, São Paulo State University (UNESP), Araçatuba, São Paulo, Brazil.

* Instituto Latino Americano de Pesquisa e Ensino Odontológico (ILAPEO), Curitiba, Paraná, Brazil.

*** Doctoral Program in Dentistry, Oral and Maxillofacial Surgery, School of Dentistry of Araçatuba, São Paulo State University (UNESP), Araçatuba, São Paulo, Brazil. 
rial, thus promoting a faster recovery of the patient to normal activities (Johansson et al.; Rothamel et al., 2009).

The posterior ridge rehabilitation of the atrophic maxilla represents one of the most challenging events in implantology. The bone with reduced quantity and quality severely affects the prognosis of implant therapy in these regions. The elevation of the sinus membrane with bone graft offers the opportunity to successfully place endosseous implants in previously unsuitable edges (Gapski et al., 2006; Stübinger et al., 2010; Sul et al., 2008). Histological and histomorphometric analysis of the regenerated tissue in maxillary sinuses will provide essential information about the nature and volume of the formed bone tissue, and the direct application of these results will improve the knowledge about titanium implants and their ability to maintain osseointegration.

Given the possibility of using alternative biomaterials for bone reconstruction in maxillary atrophy, this study was proposed to analyze clinically and histologically the allogen bone graft behavior. Bilateral sinus lifting procedure were performed in a same patient, the analysis were made after 6 and 9 months, respectively.

The hypothesis presented by the authors was that this biomaterial would have a poor biological behavior during the process of bone repair, as much as 6 to 9 months after its use in the reconstruction of atrophic ridges and elevation of the maxillary sinus floor. To confirm this hypothesis it was performed a clinical and histological evaluation of the grafted areas.

\section{CASE REPORT}

A leukoderm, female, 55 years old patient sought dental care for oral rehabilitation with dental implants and implant supported fixed prosthesis in the maxilla.

During the interview the patient reported to have hypertension and hypothyroidism controlled by medication. On clinical examination was found the existence of an overdenture retained by a bar bolted to 3 implants in the maxilla in the region corresponding to teeth 14,13 and 24 . In the panoramic radiograph was initially demonstrated the need for bilateral maxillary sinus floor elevation to allow implant placement and enable future installation of a hybrid prosthesis. By CT scan was observed unfavorable bone conditions in height (right side), and height and thickness on the left side (Fig. 1).

The patient reported having sought oral rehabilitation with fixed implant supported prosthesis

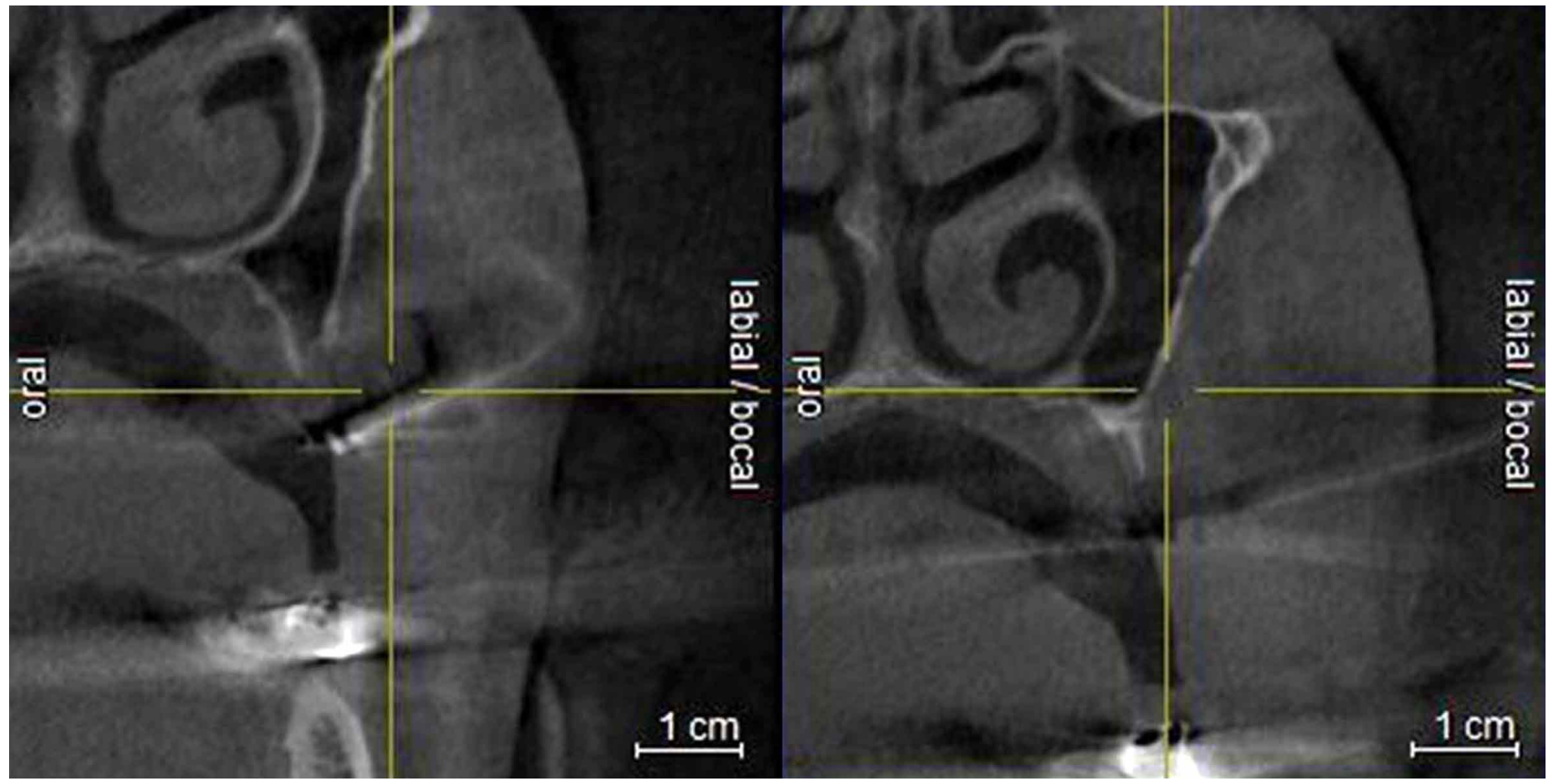

Fig. 1. Initial CT scan - right and left sides. 
BASSI, A. P. F.; VIEIRA, R. A.; MATSUMOTO, M. A.; STECKELBERG, I. M.; RAMALHO-FERREIRA, G. \& FAVERANI, L. P. The fresh frozen bone (FFBA) allograft to reconstruct the atrophic maxilla. Evaluation of the clinical and histological viability at six and nine months in the maxillary sinus. Int. J. Odontostomat., 7(2):305-313, 2013.

and that knew about the need for maxillary sinus elevation using bone graft. She has also reported having undergone two trials of this procedure without success. In the first time the patient would undergo an iliac crest bone graft in hospital environment, which was suspended by the anesthesiologist before the procedure due to her obesity. The second attempt was in an outpatient setting, a biomaterial grafting was planned, but in the transoperative period, the presence of an oroantral communication in right maxillary sinus, aborted the procedure.

Because of this history, the team opted to use fresh frozen allogen bone, from bone bank, to increase the thickness of the ridge on the left and to perform bilateral sinus lift procedure.

First surgery. Due to increased complexity and need for greater time of remodeling of the block graft; surgery was performed first on the left. An ulna ring was requested to Skeletal Muscle Tissue Bank, Hospital das Clínicas, Federal University of Paraná.

After intra and extra oral antisepsis with chlorhexidine $0.12 \%$, and infiltrative terminal anesthesia, an incision over the left ridge and a relaxing incision mesially to the implant present in the region of tooth number 23 were performed. The mucoperiosteal flap was detached to expose the area to be grafted. The osteotomy of anterior wall of the maxillary sinus was performed with a round diamond bur used in an angled piece under abundant irrigation with saline solution, the surgery continued with detachment of the sinus membrane, which had a perforation. The perforation was treated with a collagen membrane ACE (New Jersey, USA). Subsequent, three blocks were cut and adapted in the region of the bed previously prepared aiming to increase the ridge in thickness. The extremities blocks were fixed with Neodent ${ }^{\circledR}$ (Curitiba, Brazil) self-drilling screws. A piece of bone was crushed with a Neodent ${ }^{\circ}$ (Curitiba, Brazil) bone mill to fill maxillary sinus, as well as the gaps between the installed blocks. The central block was then fixed, partially closing the window of the maxillary sinus. Following the flap was sutured (Fig. 2).

Second surgery. After three months of the first procedure, the right side of the maxilla was accessed, and an opening, that previously had caused the cancellation of a surgery, could be identified in the alveolar ridge. The osteotomy of anterior wall of maxillary sinus was performed with a round diamond bur under abundant irrigation, the technique followed with detachment of the sinus membrane and elevation of sinus floor. The piece of bone was crushed with Neodent ${ }^{\circledR}$, (Curitiba, Brazil) particulate to fill maxillary sinus. A portion of bone was used to close the ridge opening (Fig. 3). The flap was repositioned and sutured (Fig. 4).

The last surgical procedure involved left and right areas were performed with 6 and 9 months of bone remodeling, respectively, to install dental implants. On these occasions, we use a 2.0 trephine for collect bone to histological analysis of the right and left maxillary sinus in a vertical direction, and to collect bone in the region of the posterior block, on the left side, in a horizontal direction.

The samples were placed in $10 \%$ formalin and sent for histological analysis. The sample 1 and 3 has suffered fractures due to its fragility. After collecting the samples implants were installed (Neodent ${ }^{\circledR}$ Curitiba, Brazil) (Fig. 5). The flaps were repositioned and sutured. Postoperative follow-up was performed through panoramic radiography.

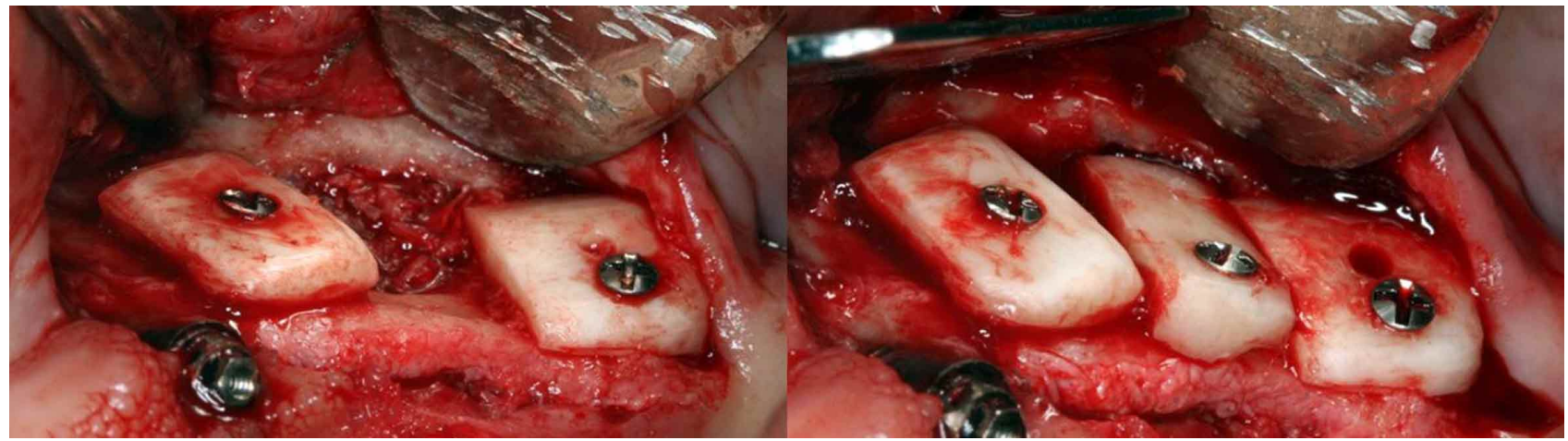

Fig. 2. Maxillary sinus filled with particles of allograft bone and ridge augmentation using the same material in blocks, the window of the maxillary sinus was closed by a central block. 


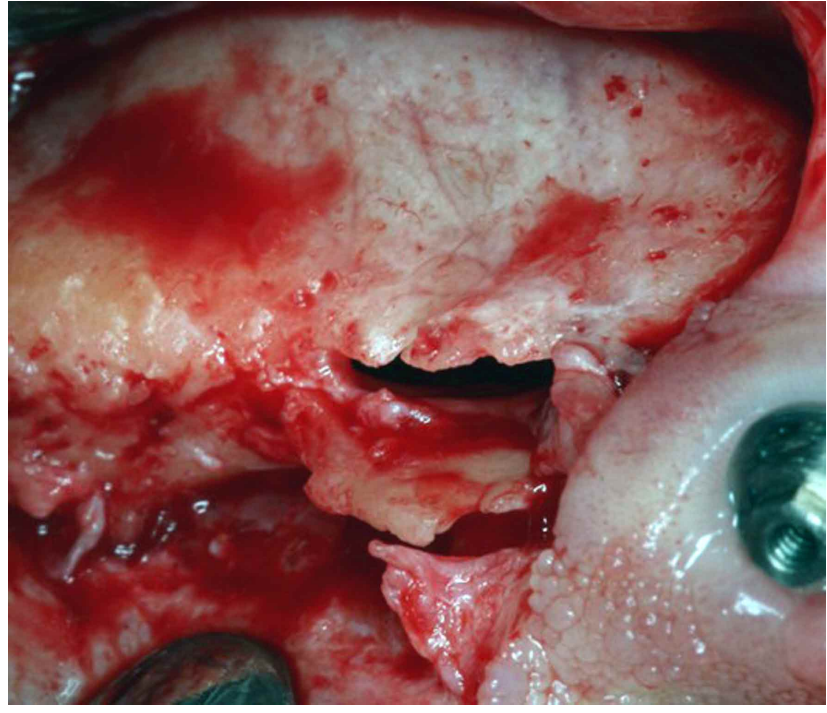

Fig. 3. Receptor bed with a fenestration on the ridge.

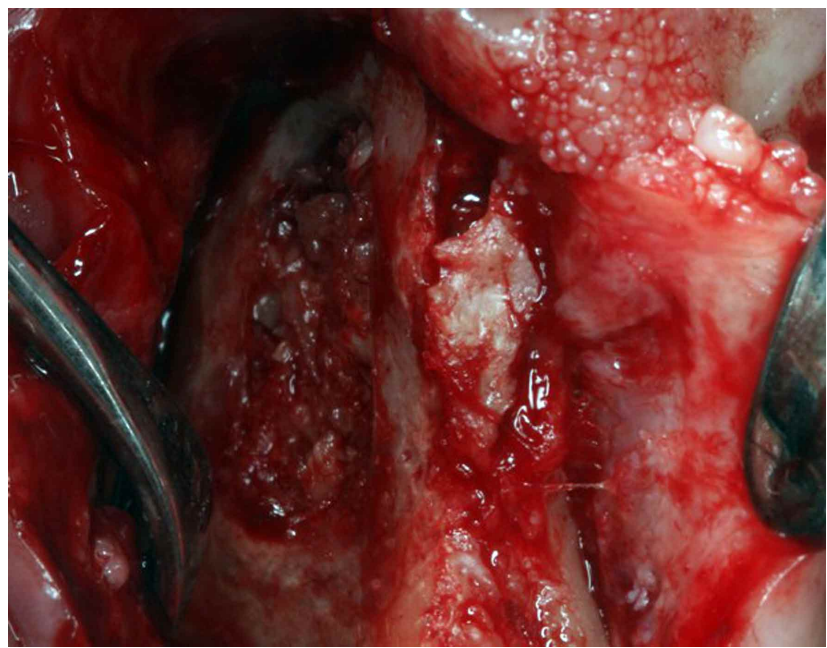

Fig. 4. A fragment of the graft was used to close the fenestration.
The specimens were fixed in $10 \%$ formalin and then washed in water for 24 hours. Subsequently were placed in 10\% EDTA for demineralization process for 10 days, with three substitutions per week. After demineralized, underwent routine histotechnical procedure and were stained with Masson Trichrome and hematoxylin and eosin.

Analysis Clinical. We confirm the viability of FFBA for reconstructive procedures previously oral rehabilitation with dental implants. Although it has characteristics that must be considered, because the quality of obtained bone either 6 and 9 months after reconstructive surgery was low, and this is one factor that could undermine the primary stability of the implant and also its osseointegration.

Analysis Histologic. Sample 1 (6 months): It was noted the presence of homologous graft fragments predominantly non-viable, morphologically identified by the presence of empty bone lacunae (Fig. 6a). Fragments in slight remodeling are also seen, which takes place from their outer surfaces, associated with osteoclastic activity (Fig. 6b); sometimes exhibiting osteoconductive behavior (Fig. 6c). The fragments are surrounded by fibrous connective tissue. The residual bone is clearly in the remodeling phase, characterized by the presence of evident basophilic reversal lines in the limit of viable bone tissue and neoformed bone (Fig. 6d).

Sample 2 (9 months): Fragments of homologous bone graft could be visualized, sometimes not viable, and sometimes in remodeling process characterized by reversion lines and the presence of cellularized bone tissue (Fig. 7a). Surrounding the fragments, there is fibrous tissue (Fig. 7b). The residual bone is shown in a clear process of remodeling (Fig.7c).

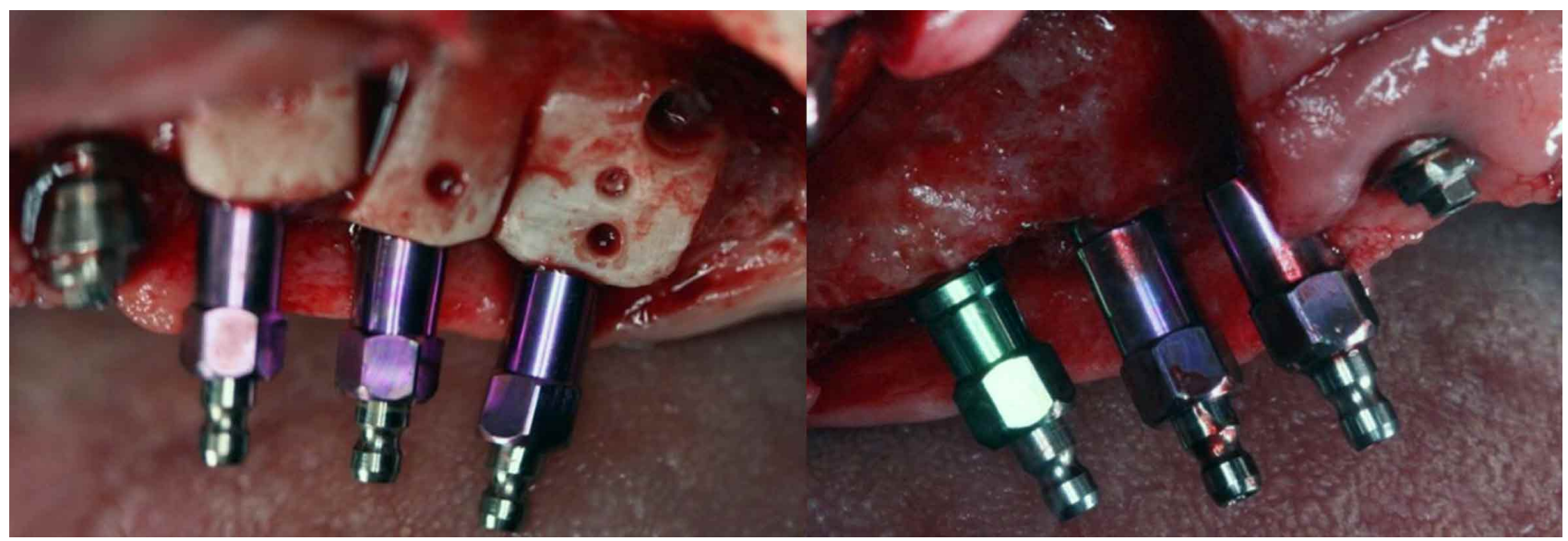

Fig. 5. Implants were installed in the right and left side. 
BASSI, A. P. F.; VIEIRA, R. A.; MATSUMOTO, M. A.; STECKELBERG, I. M.; RAMALHO-FERREIRA, G. \& FAVERANI, L. P. The fresh frozen bone (FFBA) allograft to reconstruct the atrophic maxilla. Evaluation of the clinical and histological viability at six and nine months in the maxillary sinus. Int. J. Odontostomat., 7(2):305-313, 2013.

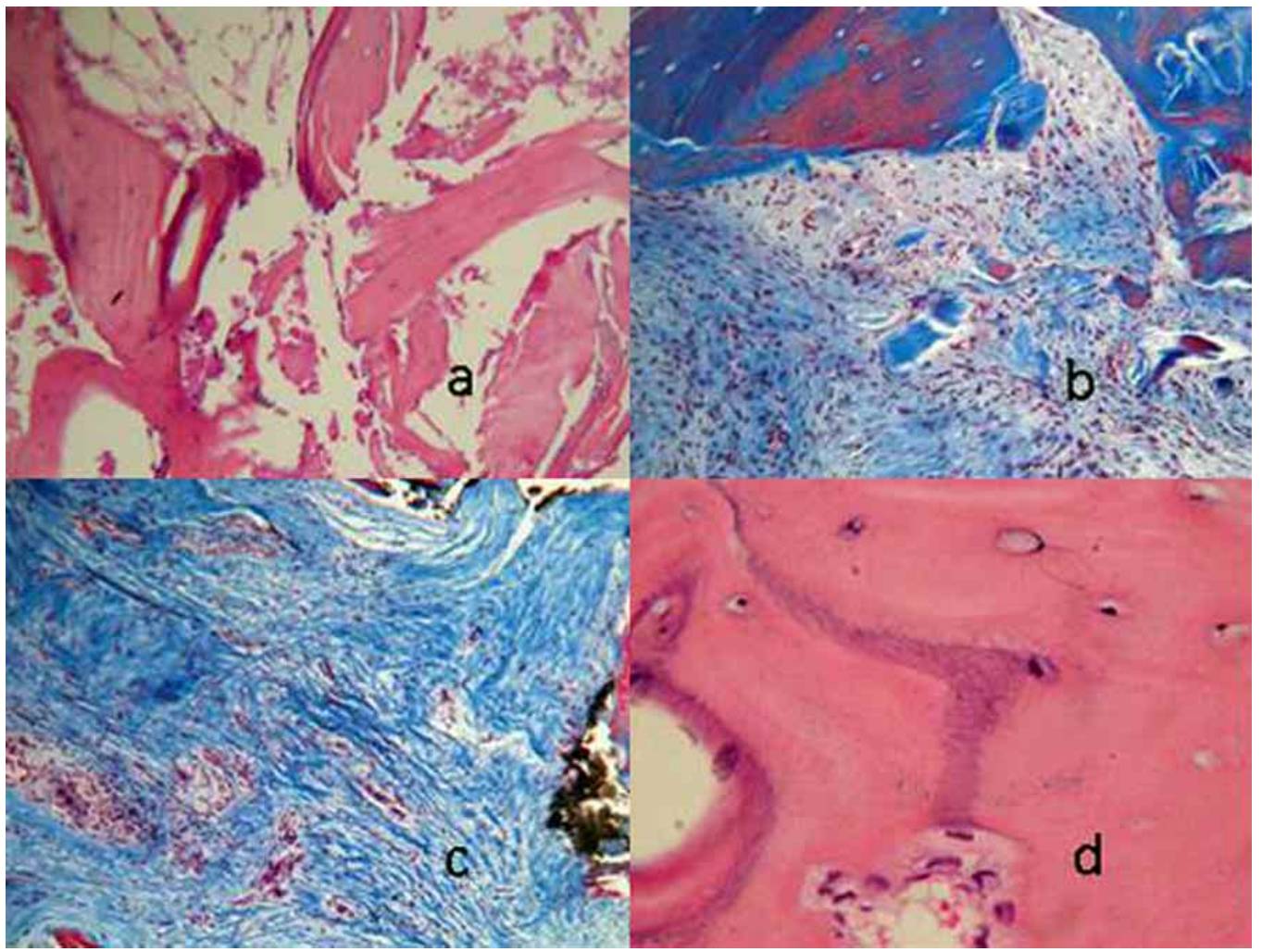

Fig. 6. Particulate allograft (6 months). a, b) Fragments of bone graft sometimes viable, sometimes acellular, c) Fibrous connective tissue between the bone fragments, d) residual bone remodeling marked by reversal lines.

Fig. 7. Particulate allograft (9 months). a) Fragments of predominantly nonviable graft, showing empty lacunae (arrows), b) Bone remodeling from the surfaces of the graft fragments marked by the reversal lines (arrows), c) Bone neoformation $\left({ }^{*}\right)$ on non-viable fragment (enx), d) residual bone rich in osteocytes (arrows) (HE a, d) $200 \mu \mathrm{m}$; b, c) $100 \mu \mathrm{m})$.

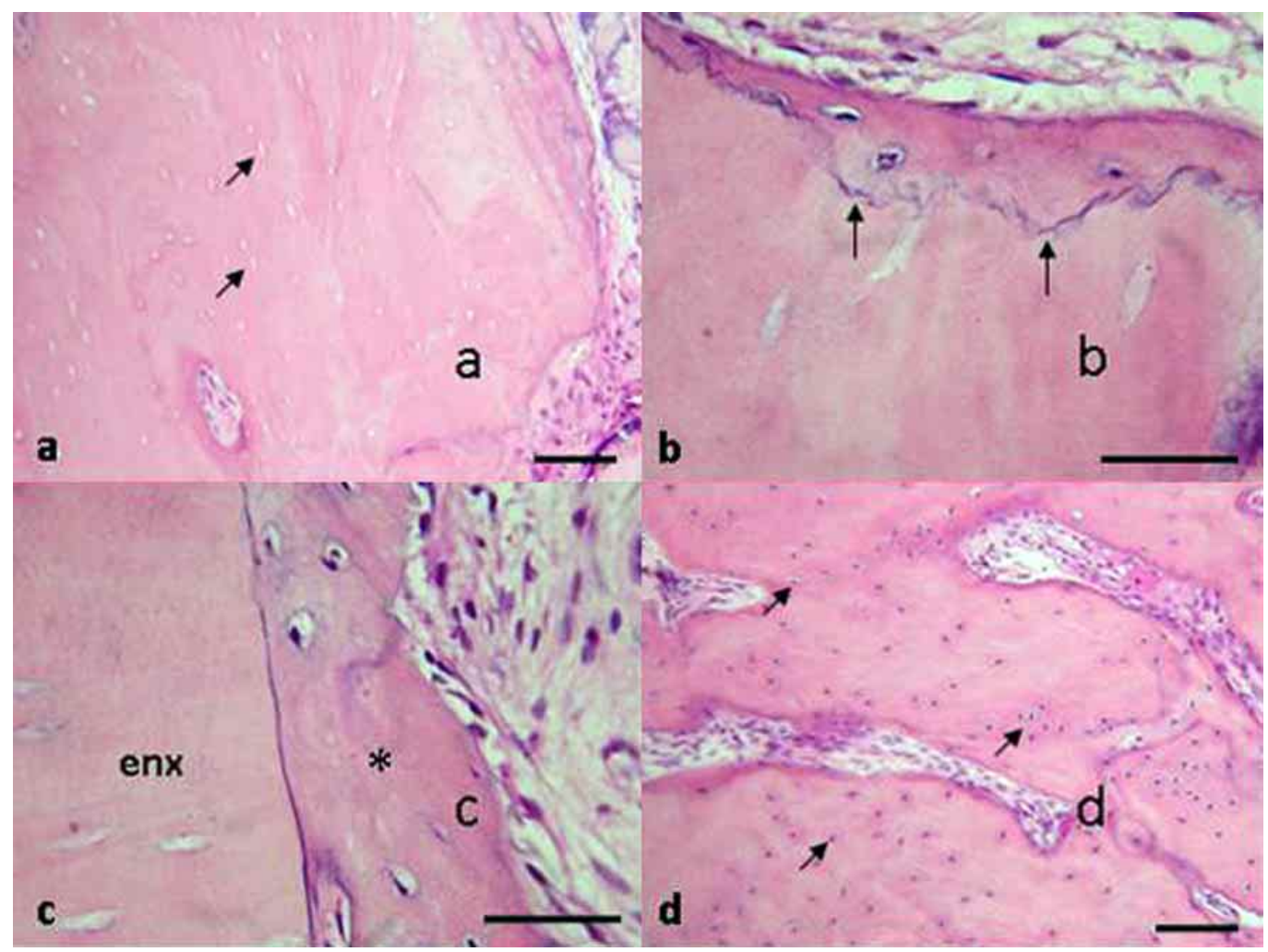


Sample 3 (9 months); In the region of the allograft block, bone tissue harvested showed empty lacunae without osteocytes, as well as the absence of cells lining the Haversian canals (Fig. 8a). Signs of incorporation were not displayed with the recipient bed
(Fig. 8b). The residual bone was found to be cellularized, predominantly mature, marked by the lamellar aspect, with the presence of lining cells on their surface (Fig. 8c) and fibrous bone marrow containing adipocytes (Fig. 8d).

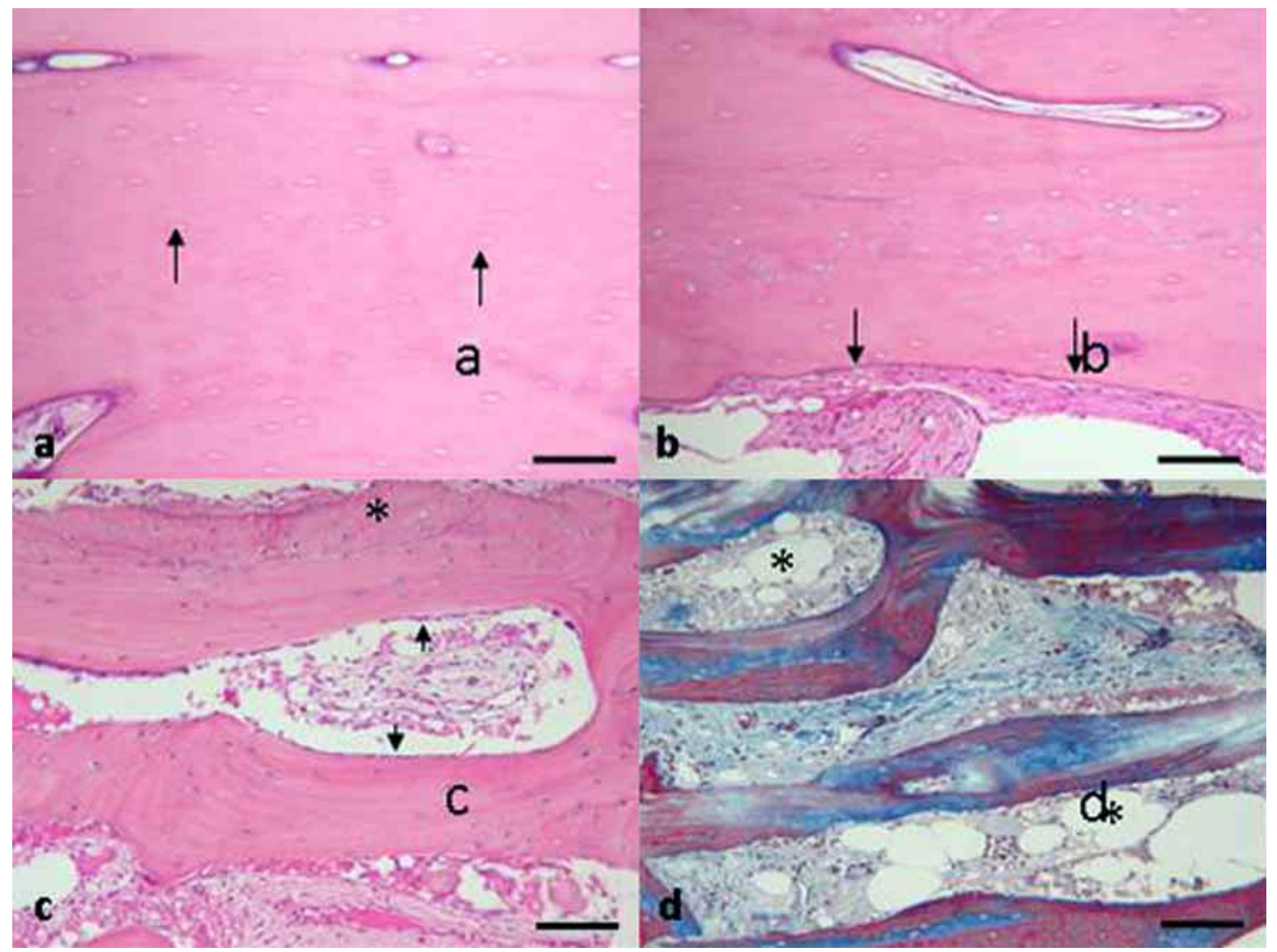

Fig. 8. Allograft block (9 months) - a) Bone graft with empty osteocyte lacunae (arrows), b) the interface region presented no signs of incorporation (arrows), c) residual bone predominantly mature (o) with signs of remodeling $\left(^{*}\right)$ and lining cells in its surface (arrows), d) bone marrow showing fat cells permeated by fibrous tissue $\left.\left(^{*}\right)(a), b\right)$ $\mathrm{HE}, 100 \mu \mathrm{m}$; c) HE, d) Trichrome Masson $200 \mu \mathrm{m}$ ).

\section{DISCUSSION}

The rehabilitation of atrophic maxilla is currently an often-encountered condition by dentists. It is a challenging situation due to its complexity and possibilities of treatment, especially when we are facing totally edentulous patients. Owing to technological improvement of implantology, in these situations we can use tilted implants, shorter implants and also reconstructions using bone grafts and/or biomaterials (Pelo et al.; Sbordone et al., 2009).
The reduced bone quantity and quality severely affects the prognosis of implant therapy in posterior maxilla, which is one of the challenging events in implantology. The elevation of the sinus floor membrane has been an important tool to assist in the rehabilitation of these areas (Landi et al., 2000).

In this respect, there are several possibilities of materials for reconstruction of the posterior maxilla. 
BASSI, A. P. F.; VIEIRA, R. A.; MATSUMOTO, M. A.; STECKELBERG, I. M.; RAMALHO-FERREIRA, G. \& FAVERANI, L. P. The fresh frozen bone (FFBA) allograft to reconstruct the atrophic maxilla. Evaluation of the clinical and histological viability at six and nine months in the maxillary sinus. Int. J. Odontostomat., 7(2):305-313, 2013.

Among these, the FFBA that has been widely used in dentistry not only in particulate form as well as in block can be detached. Many important questions concerning the prognosis of this type of treatment remain unanswered: the time of implant placement, the type of graft material, the use of membranes, and the ability of the regenerated bone to functional maintain osseointegrated dental implants are vital questions that need further study (Feng et al., 2010; Landi et al.; Schwarz et al., 2010).

Especially for its use in sinus lift procedures the particulate homogenous graft shows positive results according to the literature, although the longterm monitoring still requires further attention. Because of this, this study aimed to get a response about the time needed to place dental implants after reconstruction of these areas with FFBA. The consulted literature does not have a consensus on this, and these periods vary from 3 to 9 months after grafting (Contar et al., 2009; Kübler et al., 1999; Peleg et al., 2010).

In the present case we made a bilateral sinus floor elevation using FFBA, with surgical intervals of 3 months between each procedure. In a third surgery, right and left sides of maxilla were simultaneously reopened for the installation of dental implants, at 6 and 9 months of bone remodeling respectively, enabling the future installation of a fixed prosthesis. Clinically, with 6 months of bone remodeling in the right side, it was possible the installation of implants with low torque (10 $\mathrm{N}$ in the region of tooth 17 , and $20 \mathrm{~N}$ in the region of 16 and 15). There was primary stability and apparently viable bone tissue was removed by a trephine for histology, type IV quality bone was obtained in the region of tooth 17 , and type III in the region related to teeth 16 and 15 . The left side, with nine months of bone remodeling, received selftapping implants because of the presence of FFBA blocks, which were used to increase ridge in thickness in addition to the sinus lifting. It was possible to install implants with low torque (20 $\mathrm{N}$ in all implants) obtaining primary stability; bone quality was found to be type II in the region of teeth 24,25 and 26 . The sample obtained by trephine showed an aspect of a viable and bone. So the right maxillary sinus with 6 months of bone remodeling presented bone quality type III and IV, while the left side with bone remodeling time of 9 months showed bone quality type II, but we should also consider that this side also has received cortical blocks which may have influenced the perception of better local bone quality.
Histological analysis has confirmed the clinical findings. At 6 months, there was lack of a better bone remodeling in the region, associated to the presence of fibrous connective tissue within the collected tissue, showing us that this is not the best stage of tissue maturation to place dental implants. The 9 months period showed an improvement, with a more organized bone tissue surrounding particles of homogenous bone, what possibly had increased implant stability at the time of surgery.

Another factor that must always be considered is that this is a material with only osteconductives properties as we have seen in the microscopic view, in which there was no viable cells and prolonged resorption process.

Some authors such as Kübler et al., report that with the reopening within 4 to 6 months is possible to find new bone formation around the allografts particles, being these characteristics also found in radiographic evaluation. According to Gapski et al., the histological findings of the bone harvested with trephine after 6 months of biomaterial use, showed a bone apt to receive implants.

Even though radiographically we had good bone neoformation in our case, clinically the bone tissue at the 6-month period presented with little resistance very similar to an osteoid tissue, unlike the results found by the authors cited above. Although the stability of the implants have been obtained, due to the fact that we used a surgical technique that led to this situation (compacting implants with subinstrumentation), we feel greater safety of the implants installed in the region with 9 months postoperatively.

Stacchi et al. (2008) performed a clinical, histological and histomorphometric study using FFBA for sinus lifting procedures. The authors have treated ten patients using FFBA, and after five months, during dental implants installation, samples were collected, and processed for histological evaluation. Most samples showed new bone formation that was fully integrated with pre-existing bone. The areas of interface between new and old bone was not distinguishable. There was no evidence of inflammatory infiltrate. Histomorphometry revealed that bone percentage was $48.15 \%+14.32 \%$, and the marrow space occupied the remaining area.

We believe that the use of FFBA for rehabilitation of patients with atrophic maxilla can be a viable alternative as well as other bone substitutes. However, 
BASSI, A. P. F.; VIEIRA, R. A.; MATSUMOTO, M. A.; STECKELBERG, I. M.; RAMALHO-FERREIRA, G. \& FAVERANI, L. P. The fresh frozen bone (FFBA) allograft to reconstruct the atrophic maxilla. Evaluation of the clinical and histological viability at six and nine months in the maxillary sinus. Int. J. Odontostomat., 7(2):305-313, 2013.

as observed in this clinical case, the early reopening of these areas may compromise the clinical success, since that the newly formed bone has not adequate features to support the stabilization of an implant as the authors reported that reopen these areas with 3 to 4 months (Contar et al.; Peleg et al.). Confirming the hypothesis previously established by the authors of this paper.
There is no doubt about the increase of clinical applications of FFBA, but there are no studies available regarding the standardization of time to load implants inserted in allografts. So papers with long-term monitoring are necessary to eliminate questions that still remain to be answered in the near future.

BASSI, A. P. F.; VIEIRA, R. A.; MATSUMOTO, M. A.; STECKELBERG, I. M.; RAMALHO-FERREIRA, G. \& FAVERANI, L. P. Aloinjerto óseo fresco congelado (FFBA) en la reconstrucción del maxilar atrófico. Evaluación de la viabilidad clínica e histológica a los seis y nueve meses en el seno maxilar. Int. J. Odontostomat., 7(2):305-313, 2013.

RESUMEN: El objetivo fue analizar clínica e histológicamente el injerto óseo alógeno a los 6 y 9 meses. Una paciente sexo femenino, leucoderma de 55 años de edad consultó por atención odontológica para la rehabilitación oral con implantes y prótesis fija implanto soportada en el maxilar. Procedimientos de elevación del seno maxilar bilateralmente fueron realizados en la misma paciente, y se hicieron los análisis después del sexto y noveno mes, respectivamente. Al sexto mes, se observó una remodelación ósea deficiente de la región asociada a la presencia de tejido conectivo fibroso en el tejido analizado, demostrando que no era la mejor etapa de maduración óseo para instalar los implantes. Al noveno mes se observo una mejora, con un tejido óseo mas organizado rodeando partículas de hueso homogéneo, el cual posiblemente incrementaría la estabilidad del implante en el momento de la cirugía. No hay dudas respecto del incremento de aplicaciones clínicas del FFBA, pero no hay estudios capaces de estandarizar el tiempo de carga de los implantes instalados sobre aloinjertos. Investigaciones con seguimientos a largo plazo son necesarios para eliminar las preguntas que aun se mantienen sin respuesta.

PALABRAS CLAVE: seno maxilar, hueso humano fresco congelado, histología ósea

\section{REFERENCES}

Carvalho, P. S. P.; Bassi, A. P. F. \& Ponzoni, D. Pre-prosthetic surgery. In: Book of 21st Paulista Congress of Dentistry. Dentistry, Art and Knowledge: dentistry, implant, TMJ, implantology, surgery, geriatric dentistry. $1^{\circ}$ Ed. São Paulo, Artes Médica, 2003. pp.409-37.

Contar, C. M.; Sarot, J. R.; Bordini, J. Jr.; Galvão, G. H.; Nicolau, G. V. \& Machado, M. A. Maxillary ridge augmentation with fresh-frozen bone allografts. J. Oral Maxillofac. Surg., 67(6):1280-5, 2009.

Feng, Y.; Fang, B.; Shen, G.; Xia, Y. \& Lou, X. Reconstruction of partial maxillary defect with intraoral distraction osteogenesis assisted by miniscrew implant anchorages. Oral Surg. Oral Med. Oral Pathol. Oral Radiol. Endod., 110(3):e1-7, 2010.

Gapski, R.; Neiva, R.; Oh, T. J. \& Wang, H. L. Histologic analyses of human mineralized bone grafting material in sinus elevation procedures: a case series. Int. J. Periodontics Restorative Dent., 26(1):59-69, 2006.

Johansson, B.; Grepe, A. \& Wannfors, K. A clinical study of changes in the volume of bone grafts in the atrophic maxilla. Dentomaxillofac. Radiol., 30(3):157-61, 2001.
Kübler, N. R.; Will, C.; Depprich, R.; Betz, T.; Reinhart, E.; Bill, J. S.; et al. Comparative studies of sinus floor elevation with autologous or allogeneic bone tissue. Mund Kiefer Gesichtschir., 3(Suppl. 1):S53-60, 1999.

Landi, L.; Pretel, R. W. Jr.; Hakimi, N. M. \& Setayesh, R. Maxillary sinus floor elevation using a combination of DFDBA and bovine-derived porous hydroxyapatite: a preliminary histologic and histomorphometric report. Int. J. Periodontics Restorative Dent., 20(6):574-83, 2000

Peleg, M.; Sawatari, Y.; Marx, R. N.; Santoro, J.; Cohen, J.; Bejarano, P.; et al. Use of corticocancellous allogeneic bone blocks for augmentation of alveolar bone defects. Int. J. Oral Maxillofac. Implants, 25(1):153-62, 2010

Pelo, S.; Gasparini, G.; Moro, A.; Boniello, R. \& Amoroso, P. F. Segmental Le Fort I osteotomy with bone grafting in unilateral severely atrophied maxilla. Int. J. Oral Maxillofac. Surg., 38(3):246-9, 2009

Rothamel, D.; Schwarz, F.; Herten, M.; Ferrari, D.; Mischkowski, R. A.; Sager, M.; et al. Vertical ridge augmentation using xenogenous bone blocks: a histomorphometric study in dogs. Int. J. Oral Maxillofac. Implants, 24(2):243-50, 2009 
BASSI, A. P. F.; VIEIRA, R. A.; MATSUMOTO, M. A.; STECKELBERG, I. M.; RAMALHO-FERREIRA, G. \& FAVERANI, L. P. The fresh frozen bone (FFBA) allograft to reconstruct the atrophic maxilla. Evaluation of the clinical and histological viability at six and nine months in the maxillary sinus. Int. J. Odontostomat., 7(2):305-313, 2013.

Sbordone, L.; Toti, P.; Menchini-Fabris, G. B.; Sbordone, C.; Piombino, P. \& Guidetti, F. Volume changes of autogenous bone grafts after alveolar ridge augmentation of atrophic maxillae and mandibles. Int. J. Oral Maxillofac. Surg., 38(10):1059-65, 2009.

Schwarz, F.; Jung, R. E.; Fienitz, T.; Wieland, M.; Becker, J. \& Sager, M. Impact of guided bone regeneration and defect dimension on wound healing at chemically modified hydrophilic titanium implant surfaces: an experimental study in dogs. J. Clin. Periodontol., 37(5):47485, 2010.

Stacchi, C.; Orsini, G.; Di lorio, D.; Breschi, L. \& Di Lenarda, R. Clinical, histologic, and histomorphometric analyses of regenerated bone in maxillary sinus augmentation using fresh frozen human bone allografts. J. Periodontol., 79(9):1789-96, 2008

Stübinger, S.; Saldamli, B.; Landes, C.A. \& Sader, R. Palatal piezosurgical window osteotomy for maxillary sinus augmentation. Int. J. Oral Maxillofac. Surg., 39(6):6069, 2010

Sul, S. H.; Choi, B. H.; Li, J.; Jeong, S. M. \& Xuan, F. Histologic changes in the maxillary sinus membrane after sinus membrane elevation and the simultaneous insertion of dental implants without the use of grafting materials. Oral Surg. Oral Med. Oral Pathol. Oral Radiol. Endod., 105(4):e1-5, 2008.

\section{Correspondence to} Leonardo Perez Faverani

Rua Afonso Pena, 2000

Edifício Aguillera, Bloco 4, Ap. 11

Jardim Paulista

CEP: 16011-195

Araçatuba-SP

BRAZIL

Tel: +55 (18) 8112-1750

Email: e-jardim@bol.com.br

Received: 03-03-2013

Accepted: 14-04-2013 